\title{
中・長距離ランナーにおける箢線維組成，毛細血管， 酸化醭素活性と有酸素的作業能との関係
}

\author{
満 園 良一* 勝 田茂** 金 尾 洋 治*** \\ 田判健 - ${ }^{* * * *}$ 永井純**
}

\section{RELATIONSHIP BETWEEN MUSCLE FIBER COMPOSITION, CAPILLARY SUPPLY, OXIDATIVE ENZYME ACTIVITY AND AEROBIC WORK CAPACITY IN MIDDLE- AND LONG-DISTANCE RUNNERS}

\author{
Ryouichi Mitsuzono, Shigeru Katsuta, Youji Kanao, \\ KEN-ICHI TABUCHI and JUN NAgAI
}

\begin{abstract}
It was the purpose of this study to examine the property of skeletal muscle fiber in middle- and long-distance runners, and to evaluate the relationship between the property of skeletal muscle fiber and aerobic work capacity.

Biopsy samples were taken from $M$. vastus lateralis of 23 middle- and long-distance runners, and analyzed for muscle fiber composition, capillary supply and SDH activity. Aerobic work capacity was measured on a treadmill with continuous method.

The mean value for $\% \mathrm{ST}$ in $\mathrm{M}$. vastus lateralis was $61.3 \%$, and the muscle fiber distribution showed the tendency of slow type. The crosssectional area of ST and FT fibers ranged approximately from $3,000 \mu \mathrm{m}^{2}$ to $13,000 \mu \mathrm{m}^{2}$, and the cross-sectional area of ST fiber tended to be larger than that of $\mathrm{FT}$ fiber. The mean values for $\mathrm{CD}, \mathrm{C} / \mathrm{F}$ ratio, and $\mathrm{CC}(/ \mathrm{ST})$ as capillary supply were $279 / \mathrm{mm}^{2}, 1.62$ and 5.7 , respectively. The mean value for SDH activity was $5.86 \mu \mathrm{moles} / \mathrm{g} / \mathrm{min}$, and was lower than reported previously for elite runners. In addition, $\mathrm{SDH}$ activity correlated with $\% \mathrm{ST}$ and $\mathrm{CC}(/ \mathrm{ST})(\mathrm{r}=0.480$, $\mathrm{p}<0.05, \mathrm{r}=0.640, \mathrm{p}<0.01)$. On the other hand, the mean value for $\dot{\mathrm{V}} \mathrm{O}_{2} \max$ was $68.5 \mathrm{ml} /$ $\mathrm{kg} / \mathrm{min}(4,066 \mathrm{ml} / \mathrm{min})$, while $\dot{\mathrm{O}}_{2} @ \mathrm{AT}$ averaged $45.9 \mathrm{ml} / \mathrm{kg} / \mathrm{min}(2,756 \mathrm{ml} / \mathrm{min})$. And it was found that $\dot{\mathrm{V}} \mathrm{O}_{2} \max$ and $\dot{\mathrm{V}} \mathrm{O}_{2} @ \mathrm{AT}$ correlated significantly with \% ST, CC (/ST) and SDH activity. Particularly, $\dot{\mathrm{V}}_{2} \max$ was most strongly related to $\mathrm{SDH}$ activity $(\mathrm{r}=0.612, \mathrm{p}<0.01)$.

The results of this study suggest that in regard to middle- and long-distance runners, structural characteristics of the ST fiber and capillary are some of the indispensable factors to regulate such a functional property as SDH activity and that the distinctive characteristics of the skeletal muscle fiber might possibly influence aerobic work capacity to a great extent.
\end{abstract}

(J.Physical Fitness Japan 1986, $35:$ 182 191)

key words : capillary supply, SDH activity, $\dot{\mathrm{V}}_{2} @ \mathrm{AT}$, middle and long-distance runners

* 久留米大学商学部 福岡県久留米市御井町

** 筑波大学体育科学系 茨城県新治郡桜村天王台

*** 愛知県立看護短期大学 愛知県名古屋市守山区上志段味東谷

$* * * *$ 関東中央病院 東京都世田谷区上用賀
Faculty of Commerce, Kurume University, Fukuoka, 830.

Institute of Health and Sports Science, The University of Tsukuba, Ibaraki, 305.

Aichi Prefectural Junior College of Nursing, Aichi, 463.

Kantou Central Hospital, Tokyo, 154. 


\section{I. 緒}

ヒトの骨格筋線維は, ニードル・バイオプシー 法の導入と分析法の進歩により, Fiber type, Capillary supply，諸酵素や基質などの特性につ いて検討されるようになった ${ }^{1 / 9115 / 1924 / 26)}$. 中・長 距離ランナーを対象とした研究に拈いても，パフ オーマンスを規定する生理学的要因として，主働 筋の諸特性が検べられ，骨格筋線維にみられるト レーニングの影響なども明らかにされてきてい る45/9124)25/26/29). 例えば, 長距離ランナーの主働 筋は, ST 線維の構成比が高く, 高い酸化酵素活 性を示すことが認められている.しかしながら， わが国に括いては，中・長距離ランナーに限ら ず，各スポーツ競技者の骨格筋線維の諸特性に関 する研究報告は極めて少ない(1718). とりわけ， 中・長距離ランナーの Capillary supply につい て検討した報告は，いまのところみあたらない。

本研究は, 組織化学的および生化学的手法によ り, 高い持久的能力をるつ中・長距離ランナーの 骨格筋線維に拈ける諸特性について明らかにし， これら骨格筋線維の諸特性と有酸素的作業能との 関係について検討することを目的とした.

\section{II. 実 験 方 法}

\section{A. 被検者}

被検者は, 過去 6 年以上にわたりトレーニング を積んできた男子中・長距離 ランナー23名であ る.これらのなかには，全日本大学対校駅伝大会 および関東学生対校東京一箱根間往復駅伝大会に 出場した17名が含まれているまた，被検者の $1,500 \mathrm{~m}, 5,000 \mathrm{~m}$ 走に打けるパフォーマンス・レ ベルは，それぞれ平均タイムで 4 分 01 秒 7,15 分 04秒 7 である.ささらに，表 1 に，被検者の身体的

Table 1. Characteristics of subjects.

\begin{tabular}{|c|c|c|c|c|}
\hline & Mean & S.D. & Max. & Min. \\
\hline (yrs) & 21.2 & 1.9 & 25.0 & 19.0 \\
\hline Height $(\mathrm{cm})$ & 170.0 & 3.3 & 176.0 & 165.0 \\
\hline Weight (kg) & 59.5 & 3.6 & 65.2 & 53.1 \\
\hline$\%$ Fat $(\%)$ & 10.2 & 1.5 & 14.6 & 9.0 \\
\hline
\end{tabular}

特性を示した. 体脂肪率(\% Fat) は，上腕背部と 肩甲骨下部の皮下脂肪厚から推定した ${ }^{20)}$.

\section{B. 筋組樴の採取方法}

被検筋は，右側の外側広筋 (M. vastus lateralis)であり, ニードル・バイオプシー法㹸によっ て, 膝蓋骨上端から 6〜 $7 \mathrm{~cm}$ の部位に打ける20〜 $30 \mathrm{mg}$ の筋組織を 2 片採取した. 採取した筋組織 は液体窒素により冷やされたイソペンタン中で, 瞬間凍結後, 1 片が組織化学的分析 (Muscle fiber composition, Capillary supply), むら 1 片が生化 学的分析 (Succinate dehybrogenase activity) $に$ 用いられた.これらの筋組織は, 分析するまで夜 体窒素中に冷凍保存された。

\section{C. 組織化学的および生化学的分析}

組織化学的分析用の筋組織については, $-20^{\circ} \mathrm{C}$ のクリオスタット(Bright 社製 FS-FCS 型)によ り, 厚さ $10 \mu \mathrm{m}$ の連続凍結切片を作成した. 各切 片飞, Myosin ATPase ${ }^{23)}$, DPNH-diaphorase ${ }^{21)}$, Amylase PAS"の染色をそれぞれ施した.

Myosin ATP ase 染色を施した標本から， Gollnick ら ${ }^{9)}$ の分類方法にしたがい， ST(Slowtwitch)抽よ゙ FT(Fast-twitch)の 2 線維に分 け，総筋線維数に対する各 ST, FT 線 維の比率 から筇線維構成比 (\% ST, \% FT) を求めた. DPNH-diaphorase 染色の施された標本の写真資 料から，フィルム解析装置 (ナック社製スポーテ ィアス GP 2000)を用いて, ST・FTの各筋線維 の平均横断面積を算出した。ささらに, ST・FT の 各筋線維横断面積と筋線維構成比から, 全体に占 める ST 線維の面積比 (\% area ST) を求 めた. Amylase PAS 染色の施された標本の写真資料に ついても, $1 \mathrm{~mm}^{2}$ あたりの毛細血管数 (CD ; Capillary density), CD を同じ範囲内にある筋線維数 で除した C/F ratio (Capillary per fiber), ST・ FT の各筋線維 1 本あたりをとり囲んでいる毛 細 血管数 (CC ; Mean number of capillaries in contact with fiber)をそれぞれ算出した.

生化学的分析用の筋組織は筋重量を秤量した 後, 均等質化された. その後, Sembrowich ら ${ }^{271}$ の方法にしたがい，䖝光法によりコハク酸脱水素 酵素 (SDH) 活性を測定した。 


\section{D. 有酸来的作莱能の測定方法}

被検者は, 30分〜 1 時間の安静状態を保った 後, 斜度 $0^{\circ}$ のトレッドミル走での Exhaustive 運 動を行った. 走行負荷は, 分速 $180 \mathrm{~m}$ で 4 分間 走 行した後, Exhaustion に至るまで 1 分毎に $10 \mathrm{~m}$ ずつ走速度を増加させる負荷漸増法を用いた。呼 気ガスはダグラス・バッグ法により，運動開始後 3 分めから Exhaustion に至るまで連続的に採気 し, 酸素摂取量 $\left(\mathrm{VO}_{2}\right)$ を算出した。なお, 換気量 $\left(\dot{\mathrm{V}}_{\mathrm{E}}\right)$ は乾式ガスメーター(品川社製)で計量し, 呼 気ガスの分析は, 酸素分析器 (OM-11; Beckman 社製) および二酸化炭素分析器 (LB-2; Beckman 社製）により行った. 両分析器の較正は, ショラ ンダー微量ガス分析器により分析された標準混合
ガスを用いた。

最大酸素摂取量 $\left(\dot{\mathrm{V}} \mathrm{O}_{2} \mathrm{max}\right)$ が得られたかどうか の判定は, $\dot{\mathrm{V}} \mathrm{O}_{2}$ のレベル・オフ, ガス交換比 $(\mathrm{R}>$ 1.0)を基準として用いた。 また，採気と同時に， 胸部誘導法により心拍数 (HR ; Heart rate) を連 続して記録した。

さらに，最大下走運動中に打殀有酸素的作業 能の指標として, 血中乳酸の蓄積開始点とされる 無酸素的作業間值(AT; Anaerobic threshold)を 用いた. AT の判定には, Wasserman $ら^{331}$, Davis $ら^{6)}$ の呼気ガス法による判定規準にもとついて行 った.

Table 2. Muscle fiber composition and SDH activity in middle- and longdistance runners.

\begin{tabular}{cccrrc}
\hline Subjects & $\begin{array}{c}\% \text { ST } \\
(\%)\end{array}$ & $\begin{array}{c}\% \text { area ST } \\
(\%)\end{array}$ & $\begin{array}{r}\text { area ST } \\
\left(\mu \mathrm{m}^{2}\right)\end{array}$ & $\begin{array}{c}\text { area FT } \\
\left(\mu \mathrm{m}^{2}\right)\end{array}$ & $\begin{array}{c}\text { SDH activity } \\
(\mu \mathrm{moles} / \mathrm{g} / \mathrm{min})\end{array}$ \\
\hline T. K. & 68.5 & 65.7 & 9,856 & 11,211 & 7.10 \\
H. S. & 51.0 & 52.5 & 7,381 & 6,953 & 4.00 \\
T. Ka. & 60.5 & 65.5 & 6,610 & 5,323 & 3.84 \\
Y. M. & 76.7 & 75.5 & 5,826 & 6,233 & 6.27 \\
M. S. & 67.5 & 76.7 & 12,790 & 8,066 & 12.35 \\
M. N. & 71.0 & 73.6 & 5,785 & 5,082 & 6.19 \\
S. T. & 63.5 & 59.1 & 5,469 & 6,575 & 5.25 \\
Y. K. & 34.9 & 35.9 & 4,391 & 4,203 & 3.88 \\
S. K. & 50.3 & 48.9 & 8,407 & 8,884 & 3.53 \\
H. M. & 66.5 & 61.5 & 4,801 & 5,957 & - \\
T. F. & 35.8 & 38.7 & 4,390 & 3,869 & 4.39 \\
S. F. & 54.5 & 68.3 & 7,124 & 3,969 & 2.98 \\
\hline Y. Ma. & 65.7 & 71.4 & 9,581 & 7,350 & 6.66 \\
S. Y. & 57.3 & 64.1 & 4,250 & 3,189 & 7.13 \\
S. Ts. & 61.6 & 73.2 & 8,217 & 4,815 & 3.57 \\
T. O. & 62.8 & 67.1 & 9,611 & 7,957 & 7.53 \\
T. A. & 72.7 & 77.4 & 4,814 & 3,744 & 6.66 \\
A. N. & 66.6 & 66.6 & 4,796 & 4,800 & 4.66 \\
K. A. & 63.3 & 62.7 & 4,251 & 4,369 & 6.66 \\
R. M. & 63.5 & 63.7 & 4,544 & 4,498 & 6.74 \\
M. Y. & 72.4 & 71.6 & 5,496 & 5,707 & 9.68 \\
S. Ta. & 56.5 & 59.4 & 10,471 & 9,280 & 7.10 \\
K. M. & 78.2 & 70.2 & 7,754 & 11,787 & 5.57 \\
\hline Mean & 61.3 & 63.4 & 6,815 & 6,250 & 5.86 \\
S. D. & 11.1 & 11.0 & 2,354 & 2,319 & 2.23 \\
\hline
\end{tabular}




\section{III. 実 験 結 果}

\section{A. 骨格筋線維の各特性}

表 2 は, 筋線維組成と SDH 活性の分析結果を 示したものである．破線より上段の12名は，中距 離種目を得意としており，破線より下段の11名 は，長距離種目を得意としている。ただしこれ は走パフォーマンスによる分類ではなく，各被検 者の走種目に数ける出場頻度, およびトレーニン グ内容によった.

筋線維組成は, 構成比 (\% ST), 面積比 (\% area ST) ともに, 幾分 ST 線維の構成比が高い遅筋型 の傾向を示していた $(\% \mathrm{ST} ; 61.3 \pm 11.1 \%, \%$ area ST ; 63.4 $111.0 \%)$. しかしながら, 中距離を 得意とする12名の筋線 維 組成は， 2 名か3 $35 \%$ 前 後，3名が50\%台の\%STをそれぞれ示してお り，50\%台の\%ST が 2 名しかみられなかった長 距離を得意とする11名に比べると，広範囲にわた っていた. ST および FT の各筋線維横断面積は, $3,000 \mu \mathrm{m}^{2}$ から $13,000 \mu \mathrm{m}^{2}$ の範囲に分 布してお り, ST 線維の横断面積が, FT 線維の横断面積よ りも大きい傾向にあった. SDH 活性は, $5.86 \pm$ $2.23 \mu \mathrm{moles} / \mathrm{g} / \mathrm{min}$ の平均値であったが, 1 名の 被検笳のみが $12.35 \mu \mathrm{moles} / \mathrm{g} / \mathrm{min}$ と他に比べ高 い值を示していた。

表 3 は, Capillary supply について, CD, C/F ratio, CC の分析結果を示したるのである．表 2 と同様に，破線より上段他距離を得意とする者 について, 破線より下段に長距離を得意とする者 について分けて示した。

単位面積 $\left(1 \mathrm{~mm}^{2}\right)$ あたりの毛細血管数である $\mathrm{CD}$ と, $\mathrm{CD}$ を同じ $1 \mathrm{~mm}^{2}$ あたりの筋線維数で除 した $\mathrm{C} / \mathrm{F}$ ratio は, 被検者間で大きなばらつきが みられた。 また， ST 線維抢よび FT 線維をとり 囲む毛細血管数 CC は, FT 線維位し $\mathrm{ST}$ 線維 の方に有意に多く認められた $(\mathrm{p}<0.01)$.

骨格筋線維の諸特性間については, Capillary supply としての CC(/ST) と SDH 活性, および $\% \mathrm{ST}$ とSH 活性との関係を図 1 亿示したが, $\mathrm{CC}(/ \mathrm{ST})$ と SDH 活性との間に最も高い相関係数 が認められた. SDH 活性に対しては, \% area ST
Table 3. Capillary supply in middle- and long-distance runners.

\begin{tabular}{|c|c|c|c|c|}
\hline \multirow[t]{2}{*}{ Subjects } & \multirow{2}{*}{$\begin{array}{c}\mathrm{CD} \\
\left(/ \mathrm{mm}^{2}\right)\end{array}$} & \multirow{2}{*}{$\begin{array}{l}\mathrm{C} / \mathrm{F} \\
\text { ratio }\end{array}$} & \multicolumn{2}{|c|}{$\mathrm{CC}$} \\
\hline & & & $(/ \mathrm{ST})$ & $(/ \mathrm{FT})$ \\
\hline T. K. & 242 & 1.82 & 7.0 & 5.4 \\
\hline H. S. & 340 & 1.52 & 5.9 & 4.2 \\
\hline T. Ka. & 290 & 1.51 & 4.8 & 4.4 \\
\hline Y. M. & 312 & 1.56 & 6.8 & 3.1 \\
\hline M. S. & 208 & 1.74 & 6.6 & 4.6 \\
\hline M. N. & 316 & 1.67 & 5.5 & 4.4 \\
\hline S. T. & 275 & 1.71 & 5.7 & 4.9 \\
\hline Y. K. & 261 & 1.52 & 5.1 & 4.5 \\
\hline S. K. & 206 & 1.69 & 4.9 & 5.6 \\
\hline H. M. & - & - & - & - \\
\hline T. F. & 210 & 1.52 & 4.6 & 5.3 \\
\hline S. F. & 262 & 1.59 & 4.9 & 5.2 \\
\hline Y. Ma. & 360 & 1.52 & 5.8 & 3.7 \\
\hline S. Y. & 274 & 1.57 & 6.5 & 4.3 \\
\hline S. Ts. & 368 & 1.62 & 6.0 & 5.2 \\
\hline T. 0. & 268 & 1.79 & 6.2 & 4.1 \\
\hline T. A. & 298 & 1.80 & 6.1 & 3.7 \\
\hline A. N. & 330 & 1.46 & 6.5 & 4.7 \\
\hline K. A. & 314 & 1.43 & 5.9 & 5.0 \\
\hline R. M. & 348 & 1.75 & 6.8 & 4.3 \\
\hline M. Y. & 255 & 1.86 & 6.8 & 4.7 \\
\hline S. Ta. & 223 & 1.81 & 5.6 & 4.7 \\
\hline K. M. & 206 & 1.45 & 4.5 & 4.8 \\
\hline Mean & 279 & 1.62 & $5.7^{*}$ & $4.5^{*}$ \\
\hline S. D. & 51 & 0.15 & 0.9 & 0.7 \\
\hline
\end{tabular}

$\mathrm{CD}$ : Capillary density, $\mathrm{C} / \mathrm{F}$ ratio : Capillaries per fiber, CC : Mean number of capillaries in contact with fiber. ${ }^{*}$ : Significantly different between $\mathrm{CC}$ (/ST) and $\mathrm{CC}(/ \mathrm{FT}), \mathrm{p}<0.01$.

$(\mathrm{r}=0.475, \mathrm{p}<0.05), \mathrm{C} / \mathrm{F}$ ratio( $\mathrm{r}=0.518, \mathrm{p}<0.05)$ との関係に扣いても有意な相関関係が得られた.

\section{B. 有酸素的作業能}

表 4 は，有酸素的作業能の指標となる，最大運 動時および AT 時に測定された呼吸循環 系機 能 の結果を示したものである. 最大運動時, および AT 時に括ける呼吸循環系機能の各変数は, 表 4 の最大值と最小值の範囲にみられるように，厷範 囲にわたっていた。 また，AT 時に拈ける $\mathrm{VO}_{2}$, すなわち $\dot{\mathrm{VO}}_{2} @ \mathrm{AT}$ は, $57.3 \sim 75.0 \% \dot{\mathrm{VO}}_{2} \max$ の 範囲に相当していた。 


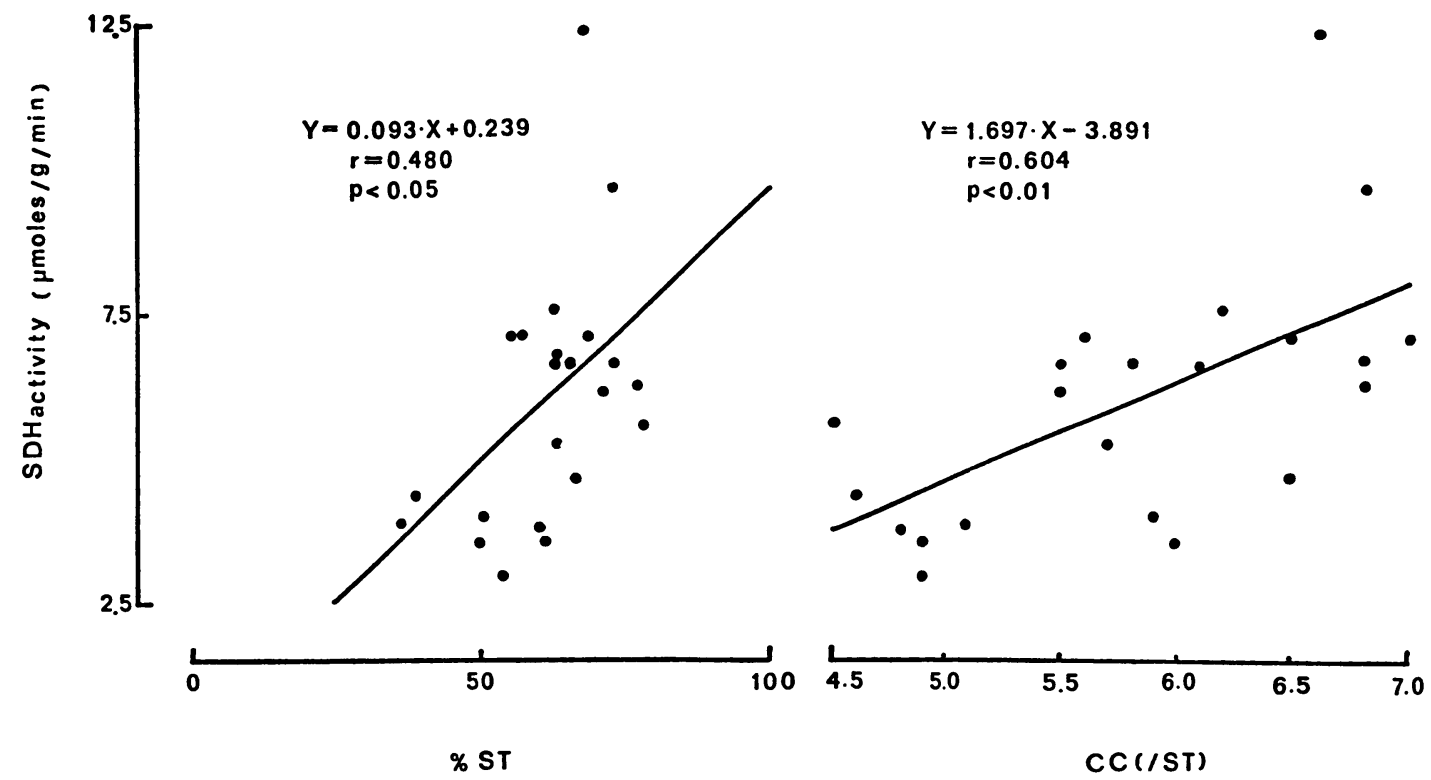

Fig. 1. Relationships between $\% \mathrm{ST}, \mathrm{CC}(/ \mathrm{ST})$ and SDH activity.

Table 4. Aerobic work capacity in middleand long-distance runners.

\begin{tabular}{|c|c|c|c|c|c|}
\hline \multicolumn{2}{|c|}{ Variables } & Mean & S. D. & Max. & Min. \\
\hline$\dot{\mathrm{V}} \mathrm{Emax}$ & $(1 / \mathrm{min})$ & 153.3 & 15.3 & 188.5 & 120.1 \\
\hline$\dot{\mathrm{V}} \mathrm{O}_{2} \max$ & $(\mathrm{ml} / \mathrm{min})$ & 4,066 & 329 & 4,637 & 3,326 \\
\hline$\dot{\mathrm{V}} \mathrm{O}_{2} \max$ & $(\mathrm{ml} / \mathrm{kg} / \mathrm{min})$ & 68.5 & 7.3 & 83.9 & 56.0 \\
\hline HRmax & (beats $/ \mathrm{min}$ ) & 197.0 & 8.8 & 209.0 & 177.0 \\
\hline E@AT & $(1 / \min )$ & 73.6 & 7.7 & 88.5 & 61.3 \\
\hline$\dot{\mathrm{V}} \mathrm{O}_{2} @ \mathrm{AT}$ & $(\mathrm{ml} / \mathrm{min})$ & 2,756 & 313 & 3,469 & 2,363 \\
\hline$\dot{\mathrm{V}} \mathrm{O}_{2} @ \mathrm{AT}$ & $(\mathrm{ml} / \mathrm{kg} / \mathrm{min})$ & 45.9 & 5.1 & 62.8 & 36.9 \\
\hline HR@AT & (beats/min) & 160.0 & 10.3 & 176.0 & 135.0 \\
\hline
\end{tabular}

VEE@T, $\dot{\mathrm{V} O} \mathrm{O}_{2} @ \mathrm{AT}, \mathrm{HR} @ \mathrm{AT}: \dot{\mathrm{VE}}, \dot{\mathrm{V}} \mathrm{O}_{2}$ and HR corresponding to anaerobic threshold.

Table 5. Correlation coefficients of the properties of skeletal muscle fiber to $\dot{\mathrm{V}} \mathrm{O}_{2} \max$ and $\dot{\mathrm{V}} \mathrm{O}_{2} @ \mathrm{AT}$.

\begin{tabular}{|c|c|c|c|c|}
\hline & \multicolumn{2}{|c|}{$\dot{\mathrm{V}} \mathrm{O}_{2} \max$} & \multicolumn{2}{|c|}{$\dot{\mathrm{V}} \mathrm{O}_{2} @ \mathrm{AT}$} \\
\hline & $\mathrm{ml} / \mathrm{min}$ & $\mathrm{ml} / \mathrm{kg} / \mathrm{min}$ & $\mathrm{ml} / \mathrm{min}$ & $\mathrm{ml} / \mathrm{kg} / \mathrm{min}$ \\
\hline$\% \mathrm{ST} \quad(\%)$ & $0.583^{* *}$ & 0.363 & $0.537^{* *}$ & 0.393 \\
\hline$\%$ area ST $(\%)$ & $0.567^{* *}$ & 0.387 & $0.446^{*}$ & 0.358 \\
\hline $\mathrm{CD} \quad\left(/ \mathrm{mm}^{2}\right)$ & 0.216 & 0.142 & 0.293 & 0.249 \\
\hline$(/ \mathrm{ST})$ & $0.509 *$ & $0.534^{*}$ & 0.358 & $0.430^{*}$ \\
\hline $\begin{array}{l}\text { SDH activity } \\
(\mu \mathrm{moles} / \mathrm{g} / \mathrm{min})\end{array}$ & $0.504^{*}$ & $0.612^{* *}$ & 0.313 & $0.450^{*}$ \\
\hline
\end{tabular}


なお， $\mathrm{VO}_{2} \max$ の判定規準として用いた，ガス

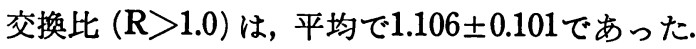
さらに，本被検者のすべてにおいて，レベル・オ フが認められたので，本被検者については，すべ て $\mathrm{VO}_{2} \max$ が得られたものと判断した.

\section{C. 骨格筋線維の各特性と有酸素的作業能との 開係}

表 5 は, 筋線維組成, Capillary supply, SDH 活性のそれぞれと, $\dot{\mathrm{V}} \mathrm{O}_{2} \max$ および $\mathrm{V}_{2} @ \mathrm{AT}$ と の相関係数を示したものである.

筋線維組成のなかでは，\%ST％ area ST と もに, $\dot{\mathrm{V}} \mathrm{O}_{2} \max$ および $\dot{\mathrm{V}} \mathrm{O}_{2} @ \mathrm{AT}$ の絶対值と有意 な相関関係が認められた. Capillary supply のな かでは, $\mathrm{CC}(/ \mathrm{ST}) の み ~ \dot{\mathrm{V}} \mathrm{O}_{2} \max , \dot{\mathrm{V}} \mathrm{O}_{2} @ \mathrm{AT}$ の相 対値との間にそれぞれ有意な相関関係が認められ た. $\mathrm{SDH}$ 活性は, $\mathrm{CC}(/ \mathrm{ST}) の$ 場合と同様に, $\dot{\mathrm{VO}}_{2}$ $\max$ および $\mathrm{VO}_{2} @ \mathrm{AT}$ の絶対值よりも，相対值と の方に高い相関係数を示す傾向にあったが, SDH 活性と $\mathrm{VO}_{2} @ \mathrm{AT}$ の絶対值との関係は, 統計的に 有意ではなかった.

\section{IV. 考察}

これまでの研究報告により，各スポーツ競技の 種目と骨格筋線維の比率 (\% ST) との間には密 接な関係が示されており，一般に，持久性競技者 の典型とされる長距離ランナーの下肢の管（腓腹 筋・外側広筋）では％ $\%$ が が優勢であるといら 報告は多い. 本研究で得られた筋線維組成は, 著 しく高いST 線維の構成比ではないが, Gollnick $ら^{9)}$, Foster ら ${ }^{81}$, Farrell らがそれぞれ報告し た $58.9 \% ， 56.0 \% ， 63.9 \%$ という長距離ランナーの \% ST とほぼ同様の範囲にある. しかしながら， Costill ら4), Rusko ら ${ }^{25)}$ の対象とした一流ランナ 一の\% ST である79.0\%拉よび78.0\%と比較する と本被検者の值は著しく低い. Costill ら"1p Rusko ら ${ }^{25)}$ の被検者はオリンピック代表を含んで おり, パフォーマンス・レベルの差が筋線維組成 にも表われたものと推察される.

また, 筋線維横断面積は, 異なるトレーニング 様式により, ST・FT 線維のタイプ別に肥大する ことが報告されている.すなわち, 筋力トレーニ
ング2432)はFT 線維を，持久的トレーニング(10)は ST線維を肥大させることが示されている.ささ に, Costill ら ら $^{\text {1 }}$ は一流陸上競技選手と非鍛練者を 比較し, 前者に拈いて ST・FT の両線維 とも肥 大を認め，とくに，長距離選手の ST 線維におい て肥大が顕著であることを指摘している．本研究 においても, ST 線維の筋線維横断面積は FT 線 維よりも大きい傾向にあり, 長年の持久的トレー ニングによる選択的肥大がみられたものと考えら れる.

骨格筋線維に拈ける毛細血管は, 主に持久的卜 レーニングにより変化すると考えられているが， 長距離ランナーに限定して Capillary supply を 検討したものは皆無である.トレーニング実験と しては, Andersen and Henriksson ${ }^{2}$ が，一般健常 者を対象とした 8 週間におよぶ持久的トレーニン グにより, 単位面積あたりの毛細血管数 CD に 約 $20 \%$ の増大 (トレーニング後の CD ; 395/ $\mathrm{mm}^{2}$ ) を報告している。 また，横断的に比較した研究と して, Hermansen and Wachtlova ${ }^{131}$ は, CD そお いてランナーやサイクリストなどの持久性競技者 と非鍛練者との間に有意な差がなく, C/F ratio （競技者で1.57，非鍛練者で1.05）に有意な差を認 めている.これに対し, Ing jer ${ }^{15}$ ' は，激しい持久的 トレーニングを行っているスキー距離競技者と非 鍛練者を比較して, 競技者の $\mathrm{CD}, \mathrm{C} / \mathrm{F}$ ratio, $\mathrm{CC}$ などが約50〜70\%高いことを示している．また， Nygaard and Nielsen ${ }^{22}$ も, 男子競泳選手との比 較に打いて同様な報告をしている。これらの持久 性競技者は, CD が465 640/ $/ \mathrm{mm}^{2}, \mathrm{C} / \mathrm{F}$ ratio が 1.49 3.07, CC(/ST)が5.2〜 7.8の範囲にあり, 本 研究の Capillary supply と比較すると, 本被検 者の CD が小さい傾向にある，このことは，本被 検者の筇線維横断面積が, ST・FT 線維ともに, 先に報告された持久性競技者のものより 2,000 $\mu \mathrm{m}^{2}$ 程大きかったことによると考えられる.

しかしながら, Capillary supplyを検討する際 には，筋細胞内に拈ける酸素などの拡散距離とい らことにより，筇線維横断面積が考慮されてい る(12)26). Nygaard and Nielsen ${ }^{221}$ は，男女の競泳 選手を被検者として極めて小さな筋線 維横断面 
積，すなわち毛細血管あたりの筋線維面積が小さ いことを報告し，筋細胞内での払散距離の重要性 を示唆している.一方, Saltin ら ${ }^{26)}$ は, 酸素の拡 散促進要因として，拻散距離以外のミトコンドリ アやミオグロビンの分布状態掞よび機能が大きく 関与していることを指摘している. 本研究に扣い ては，筇線維横断面積の肥大がみられ，毛細血管 からの拡散距離といら点では不利な結果を示して いる. しかし, 持久性競技者に関する先行研究と 比較して, 本被検者の $\mathrm{C} / \mathrm{F}$ ratio, $\mathrm{CC}$ からみた Capillary supply には差がみられないことから， 本被検者の酸素の拡散要因としては, 払散距離以 外のミトコンドリアやミオグロビンなどの影響が 大きいものと推察される.

本研究で測定した酸化酵素活性である SDH 活 性は, Gollnick らのの報告した中・長距離ランナ - $(\mathrm{n}=8)$ の $6.4 \pm 0.5 \mu \mathrm{moles} / \mathrm{g} / \mathrm{min}$ とほぼ同様な 值を示していたが, Costill ら"の21.6 $\mu \mathrm{moles} / \mathrm{g} /$ min, Rusko ら ${ }^{251 の ~} 44.6 \mu \mathrm{moles} / \mathrm{g} / \mathrm{min}$ と比較す ると著しく低い。これも，筋線維組成と同じく， パフォーマンス・レベルの差が表われたものと思 われる. また, SDH 活性は, TCA 回路のキイ・ エンザイムであり，骨格筋の有酸素的な潜在能力 の指標として, Henriksson and Reitman ${ }^{12)}$, Saltin ら 261はとらえている.そして, SDH 活性は トレーニング水準の状態を反映し，大きく変動す ることも認めている. 本被検者の SDH 活性が低 かったことは, 駅伝レース終了後 $1 \sim 2$ 週間のト レーニング・オフ期に測定したことにもよると考 えられる. 同時に，本被検者の SDH 活性が，持 久的トレーニングにより改善される可能性を示唆 している.

また％ $\mathrm{ST}$ CC $(/ \mathrm{ST})$ などと $\mathrm{SDH}$ 活性との 間に得られた有意な相関関係は，これまでの Costill $ら^{41}$, Foster $ら^{81}$, Sjödin $ら^{291}$ による長距 離ランナーを対象とした報告と必ずしも一致しな い. Costill ら"), Sjödin ら ${ }^{291}$ の報告において, 有 意な相関関係が得られなかったことは，被検者の パフォーマンス・レベルが高く，かつそのパフォ ーマンスに大きな差がみられないことによると考 えられるが，明らかでない，一方，Henriksson and Reitman ${ }^{1112)}$ は，持久的トレーニングによる Fiber type 別の SDH 活性増大が ST 線維の方に おいて有意に大きいことを示している.このこと や本研究の結果から，トレーニング初期あるいは トレーニングによる改善の低いレベルにおいて は, ST 線維の比率扰よび Capillary supply とい った筋線維の構造的特性が, SDH 活性を規定す る一要因であろらと考えられる.

有酸素的作業能は，本被検者と同等な年龄層を 対象とした山地と宮下 ${ }^{35}$ による $\dot{\mathrm{V}}_{2} \max$ の69.6 $\mathrm{ml} / \mathrm{kg} / \mathrm{min}$, Tanaka $ら^{301}$ とよる $\dot{\mathrm{VO}}_{2} \max$ の67.3 $\mathrm{ml} / \mathrm{kg} / \mathrm{min}, \dot{\mathrm{VO}}{ }_{2} @ \mathrm{AT}$ T $48.5 \mathrm{ml} / \mathrm{kg} / \mathrm{min}$ などの 平均値とほぼ等しい範囲内にある.この有酸素的 作業能と骨格筇線維の諸特性との関係について は, Foster ら ${ }^{81}$ が\% ST と $\dot{\mathrm{VO}}_{2} \max$, Costill $ら^{51}$ が SDH 活性と $\mathrm{VO}_{2} \max$, Sjödin $ら^{291}$ が CS(Citrate syntase) と OBLA(Onset of blood lactate accumulation; 血中乳酸の $4 \mathrm{~m}$ mole 地点) との 間に，長距離ランナーに拈いてそれぞれ有意な相 関関係を報告している. また, Ivy ら ${ }^{16)}$, Tesch ら ${ }^{31}$ は，骨格筋代謝を反映している AT（あるい は LT; Lactate threshold) と骨格筋線維に密接 な関係があるとしている.さらに, Farrell ら゙は, $\dot{\mathrm{V}} \mathrm{O}_{2} \max$ よりも OPLA(Onset of plasme lactate accumulation; AT に相当)時の $\dot{\mathrm{VO}}_{2}$ と\% ST と の間に，より高い相関関係を認めている. 本研究 においても, $\dot{\mathrm{V}} \mathrm{O}_{2} \max , \dot{\mathrm{V}} \mathrm{O}_{2} @ \mathrm{AT}$ と骨格筇線維の 諸特性との間に似たよらな相関関係が認められて 扣り，骨格筋線維の構造的・機能的特性が有酸素 的作業能に及ぼす影響は大きいと考えられる。し かし, Farrell らクによる報告と異なり，本研究で は $\dot{\mathrm{VO}} 2 @ \mathrm{AT}$ と骨格筋線維の諸特性との間にみら れた相関係数の方が, $\mathrm{V}_{2} \max$ の場合より低い傾 向にある. 本被検者の $\dot{\mathrm{V}} \mathrm{O}_{2} @ \mathrm{AT}$ は, 同水準の $\dot{\mathrm{V}} \mathrm{O}_{2} \max$ をむつランナーの $\dot{\mathrm{VO}}_{2} @ \mathrm{AT}$ (Tanaka ら ${ }^{301}$ の報告では $\left.48.5 \mathrm{ml} / \mathrm{kg} / \mathrm{min}\right)$ に比較して若干 低く,その変動幅 (CV 值) む大きい.これまで, トレーニング中断による AT 低下の報告はみら れないが, Willams ら ${ }^{34)}$, Tanaka ら ${ }^{301}$ はトレー ニングにより AT が有意に改善されることおよ び $\dot{\mathrm{V}} \mathrm{O}_{2} \max$ よりもAT の方が改善幅の大きいこ 
とを報告している、トレーニング・オフ期に測定 した本被検者のトレーニング状態は一様でなく， シーズンに比べ AT レベルの低下が推察され る.これらのことから，被検者内に打いて AT の 変動が大きく, $\dot{\mathrm{VO}} \mathrm{O}_{2} @ \mathrm{AT}$ と骨格筋線維の諸特性 との間に高い相関係数が得られなかったのではな いかと考えられる.

毛細血管, 酸化酵素活性および AT は,トレー ニングにより影響をうけると考えられている2101 11)14)22126)301. 本研究のトレーニング・オフ期にお いてみられた CC (/ST) および SDH 活性と有酸 素的作業能との有意な相関関係は, 今後トレーニ ング期との関連で検討することにしたい.

\section{V. 要 約}

本研究は, 中・長距離ランナー23名 (年嘢19〜 25歳）を対象として, 外側広筋からニードル・バ イオプシー法により筋組織を採取し, 骨格筋線維 の諸特性を明らかにすること，およびこれら諸特 性と,トレッドミル走行により測定された最大, 最大下運動時の有酸素的作業能との関係について 検討した.

結果は, 以下のように要約される.

1）外側広筋における ST 線維の比率は，\% ST が61.3\%,\% area ST が63.4\%の平均值であり, ST 線維寄りの傾向にあった. また, ST・FT 線 維の平均横断面積は $3,000 \sim 13,000 \mu \mathrm{m}^{2}$ の範囲に あり, ST 線維の方が FT 線維よりも大きい傾向 にあった。

2) 外側広筋における Capillary supply は, $\mathrm{CD}$ が $279 \pm 51 / \mathrm{mm}^{2}, \mathrm{C} / \mathrm{F}$ ratio が $1.62 \pm 0.15, \mathrm{CC}$

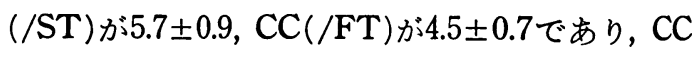
については ST 線維の周りの毛細血管数が FT 線 維のそれより有意に多かった $(\mathrm{p}<0.01)$.

3）外側広筋における $\mathrm{SDH}$ 活性は, 2.98〜 $12.35 \mu \mathrm{moles} / \mathrm{g} / \mathrm{min}$ の範囲にあり, \% ST および $\mathrm{CC}(/ \mathrm{ST})$ との間にそれぞれ $\mathrm{r}=0.480(\mathrm{p}<0.05)$, $\mathrm{r}=0.640(\mathrm{p}<0.01)$ の有意な相関関係が認められ た.

4）トレッドミル走行により測定した有酸素 的作業能は, $\dot{\mathrm{V}} \mathrm{O}_{2} \max$ が $68.5 \pm 7.3 \mathrm{ml} / \mathrm{kg} / \mathrm{min}$
(4,066 $\pm 329 \mathrm{ml} / \mathrm{min}), \dot{\mathrm{V}} \mathrm{O}_{2} @ \mathrm{AT}$ が $45.9 \pm 5.1 \mathrm{ml} /$ $\mathrm{kg} / \mathrm{min}(2,756 \pm 313 \mathrm{ml} / \mathrm{min})$ であった. この有酸 素的作業能と骨格笳線維の諸特性との関係につい ては, $\dot{\mathrm{VO}}{ }_{2} \max , \dot{\mathrm{VO}} \mathrm{O}_{2} @ \mathrm{AT}(\mathrm{ml} / \mathrm{min})$ と\% $\mathrm{ST}$ の間に $\mathrm{r}=0.583, \mathrm{r}=0.537$ (いずれる $\mathrm{p}<0.01$ ), $\dot{\mathrm{V}} \mathrm{O}_{2} \mathrm{max}, \dot{\mathrm{V}} \mathrm{O}_{2} @ \mathrm{AT}(\mathrm{ml} / \mathrm{kg} / \mathrm{min})$ と $\mathrm{CC}(/ \mathrm{ST})$ と の間に $\mathrm{r}=0.534, \mathrm{r}=0.430$ (いずれる $\mathrm{p}<0.05$ ), さ らに $\dot{\mathrm{V}} \mathrm{O}_{2} \mathrm{max}, \dot{\mathrm{VO}} \mathrm{O}_{2} @ \mathrm{AT}(\mathrm{ml} / \mathrm{kg} / \mathrm{min})$ と $\mathrm{SDH}$ 活 性との間に $\mathrm{r}=0.612(\mathrm{p}<0.01), \mathrm{r}=0.450(\mathrm{p}<0.05)$ の相関関係がそれぞれ認められた。

以上の結果は, 中・長距離ランナーにおいて, ST 線維や毛細血管などの構造的特性が SDH 活 性などの機能的特性を規定する一要因であるこ と,および骨格筇線維の構造的・機能的特性が有 酸素的作業能に大きく影響する可能性を示唆して いる.

本研究は昭和57年度文部省科学研究費, 一般研究 (C), 課題番号 558037 (研究代表者 勝田 茂) 飞上 るものである.

（受付 昭和60年 8 月 28 日）

\section{考文献}

1) Andersen, P. (1975) : Capillary density in skeletal muscle of man. Acta Physiol. Scand., 95, 203205.

2) Andersen, P. and Henriksson, J.(1977) : Capillary supply of the quadriceps femoris muscle of man : Adaptive response to exercise. J. Physiol., 270, 677-690.

3) Bergström, J.(1962) : Muscle electrolytes in man. Scand. J. Clin. L Invest. Suppl. 68.

4) Costill, D. L., Fink, W. J. and Pollock, M. L. (1976): Muscle fiber composition and enzyme activities of elite distance runners. Med. Sci. Sports, 8, 96-100.

5) Costill, D. L., Daniels, J., Evans, W., Fink, W., Krahenbuhl, G. and Saltin, B. (1976): Skeletal muscle enzymes and fiber composition in male and female track athletes. J. Appl. Physiol., 40, 149-154.

6) Davis, J. A., Whipp, B. J., Lamarra, N., Huntsman, D. J., Frank, M. H. and Wasserman, K. (1982): 
Effect of ramp slope on determination of aerobic parameters from the ramp exercise test. Med. Sci. Sports Exerc., 14, 339-343.

7) Farrell, P. A., Wilmore, J. H., Coyle, E. F., Belling, J. E. and Costill, D. L.(1979) : Plasma lactate accumulation and distance running performance. Med. Sci. Sports, 11, 338-344.

8) Foster, C., Costill, D. L., Daniels, J. T. and Fink, J.(1978) : Skeletal muscle enzyme activity, fiber composition and $\dot{\mathrm{V}} \mathrm{O}_{2}$ max in relation to distance running performance. Eur. J. Appl. Physiol., 39, 73-80.

9) Gollnick, P. D., Armstrong, R. B., Saubert IV, C. W., Piehl, K. and Saltin B. (1972) : Enzyme activity and fiber composition in skeletal muscle of untrained and trained men. J. Appl. Physiol., 33, 312-319.

10) Gollnick, P. D., Armstrong, R. B., Saltin, B., Saubert IV, C. W., Sembrowich, W. and Shephered, R. E.(1973) : Effect of training on enzyme activity and fiber composition of human skeletal muscle. J. Appl. Physiol., 34, 107-111.

11) Henriksson, J. and Reitman, J. S. (1976) : Quantitative measures of enzyme activities in type I and type II muscle fibers of man after training. Acta Physiol. Scand., 97, 392-397.

12) Henriksson, J. and Reitman, J. S. (1977) : Time course of changes in human skeletal muscle succinate dehydrogenase and cytochrome oxidase activities and maximal oxygen uptake with physical activity and inactivity. Acta Physiol. Scand., 99, 91-97.

13) Hermansen, L. and Wachtlova, M. (1971) : Capillary density of skeletal muscle in well-trained and untrained men. J. Appl. Physiol., 30, 860-863.

14) Ingjer, F. (1978) : Maximal aerobic power related to the capillary supply of the quadriceps femoris muscle in man. Acta Physiol. Scand., 104, 238240.

15) Ingjer, F. (1979) : Capillary supply and mitochondrial content of different skeletal muscle fiber types in untrained and endurance-trained men. A histochemical and ultrastructural study. Eur. J. Appl. Physiol., 40, 197-209.
16) Ivy, J. L., Withers, R. T., Van Handel, P. J., Elger, D. H. and Costill, D. L. (1980) : Muscle respiratory capacity and fiber type as determinants of the lactate threshold. J. Appl. Physiol., 48, 523-527.

17) 勝田 茂, 田㴊健一, 田中守, 宮尾英俊(1983)： スポーツ選手の利き手・非利き手における筋線維組 成と作業性肥大. 筑波大学体育科学系紀要, 6, 163170.

18）勝田 茂, 满園良一, 田㴊健一, 野村武男(1984)： 大学女子競泳選手の筋線維組成, 筇毛細血管分布と 呼吸循環系機能との関係. 筑波大学体育科学系紀 要, 7, 179-186.

19）勝田 茂, 麻場一徳, 田㴊健一, 高松 櫓, 田中守 (1985) : ニードル・ハイイオプシー法による日本人健 康青年男子の筋線維組成. 筑波大学体育 科学系紀 要, 8, 173-179.

20) Nagamine, S. (1975) : Evaluation of body fatness by skinfold measurements. JIBP Synthesis, Physiological Adaptability and Nutritional Status of Japanese., 4, 16-20.

21) Novikoff, A. B., Shin, W. and Drucker, J. (1961): Mitochondrial localization of oxidative enzymes; Staining results with two tetrazolium salts. J. Biophys. Biochem. Cyto., 9, 47-61.

22) Nygaard, E. and Nielsen, E. (1978) : Skeletal muscle fiber capillarization with extreme endur. ance training in man. Swimming Medicine VI, 282-293.

23) Padykula, H. A. and Herman, E. (1955): The specificity of the histochemical method for adenosine triphosphatase. J. Histochem. Cytochem., 3, 170-195.

24) Prince, F. P., Hikida, R. S. and Hagerman, F. C. (1976) : Human muscle fiber types in power lifters, distance runners and untrained subjects. Pflügers Arch., 363, 19-26.

25) Rusko, H., Havu, M. and Karvinen, E. (1978) : Aerobic performance capacity in athletes. Eur. J. Appl. Physiol., 38, 151-159.

26) Saltin, B., Henriksson, J., Nygaard, E. and Andersen, P. (1977) : Fiber type and metabolic potentials of skeletal muscle in sedentary man and endurance runners. Ann. N. Y. Acad. Sci., 301, 3- 
29.

27) Sembrowich, W. L., Knudson, M. B. and Gollnick, P. D. (1977) : Muscle metabolism and cardiac function of the myopathic hamster following training. J. Appl. Physiol., 43, 936-941.

28) Sjödin, B. and Jacobs, I. (1981) : Onset of blood lactate accumulation and marathon running performances. Int. J. Sports Med., 2, 23-26.

29) Sjödin, B., Jacobs, I. and KarIsson, J. (1981) : Onset of blood lactate accumulation and enzyme activities in $\mathrm{M}$. vastus lateralis in man. Int. J. Sports Med., 2, 166-170.

30) Tanaka, K., Matsuura, Y., Matsuzaka, A., Hirakoba, K., Kumagai, S., Sun, S. O. and Asano, K. (1984) : A longitudinal assessment of anaerobic threshold and distance-running performance. Med. Sci. Sports Exerc., 16, 278-282.

31) Tesch, P. A., Daniels, W. L. and Sharp, D. S. (1982): Lactate accumulation in muscle and blood during submaximal exercise. Acta Physiol. Scand., 114, 441-446.

32) Thorstensson, A., Hultén, B., Döbeln, W. and Karlsson, J. (1976): Effect of strength training on enzyme activities and fiber characteristics in human skeletal muscle. Acta Physiol. Scand., 96, 392-398.

33) Wasserman, K., Whipp, B. J. Koyal, S. N. and Beaver, M. L. (1973) : Anaerobic threshold and respiratory gas exchange during exercise. J. Appl. Physiol., 35, 236-243.

34) Willams, C. G., Wyndham, C. H., Kok, P. and Von Rahden, M. J. (1967) : Effect of training on maximum oxygen intake and on anaerobic metabolism in man. Int. Z. angew. Physiol., 24, 1823.

35）山地啓司, 宮下充正(1976)：3 年間の全身持久性卜 レーニングが陸上中・長距離選手の呼吸・循環機能 に及ぼす影響. 体育学研究, 21, 181-188. 